у студентов-менеджеров. Обнаружена закономерность влияния творческого подхода на эффективность управленческой деятельности.

Ключевые слова: подготовка к управленческой деятельности, творчество, творческий компонент, креативный потенциал, эффективность управленческой деятельности.

\author{
Olena Khartsyi, \\ PhD (Candidate of Psychological University), associate professor, \\ Tetiana Perevozna, \\ PhD (Candidate of Psychological University), associate professor, \\ Serhii Lubenets, \\ PhD (Candidate of Technical Sciences), associate professor, \\ Kharkiv State Academy of Culture, \\ 4, Bursatskyi descent, Kharkiv, Ukraine
}

\title{
PREPARING FUTURE SPECIALISTS FOR EFFICIENT ADMINISTRATION
}

The article deals with the issue of preparing future organization managers for administrative activity. The study is aimed at revealing the level of future managers' personal qualities, finding the ways of preparing them for administration. The experiment involved 198 students, who were divided into control (98 students) and experimental groups (100 students). The surveyed were of the same age and studied at the same departments. The students from the experimental group were taught systemically and the ones from the control group studied just some aspects of science considering the development of future managers' creative thinking. The results of the comparative analysis of two assessments have shown that the groups of students had different levels of personal and creative components maturity. It has been found that a good manager should have the following skills: creative, entrepreneurial, communicative and the ability to make decisions. The creative skills of managers are manifested in the psychological potential of their personality, the search for problem-based situations in the system of administration and the independency in decision making. The use of the creative approach to the administration is one of the main characteristics of a good manager. It helps to find the effective solutions and behavior patterns in new situations, to overcome the stereotype thinking and make new original decisions. Besides, the success of managers' activity also depends on the kind and level of their administration experience and skills. The influence of the creative potential on the efficiency of administration has been experimentally proved.

Keywords: efficiency of administrative activity, the creative, a creative component of the person, creative potential.

Подано до редакиії 05.07.2016

Рецензент: д. психол. н., проф. А. М. Большакова

УДК: $128+159.9$

Ирина Сергеевна Варе, аспирант кафедры теории и методики практической психологии, Южноукраинский национальный педагогический университет имени К. Д. Ушинского, ул. Старопортофранковская 26, г. Одесса, Украина

\section{САМООТНОШЕНИЕ СТУДЕНТОВ-ПСИХОЛОГОВ С РАЗНОЙ СТЕПЕНЬЮ СФОРМИРОВАННОСТИ СМЫСЛОЖИЗНЕННЫХ ОРИЕНТАЦИЙ}

Изложены результаты эмпирического исследования особенностей самоотношения будущих психологов с высокой и низкой степенью сформированности смысложизненных ориентаций. Сформулирован вывод о наличии коррелячиионных связей между смысложизненными ориентациями и показателями самоотношения. С иелью изучения специффики взаимосвязи между обозначенными переменными мы использовали методику "Смысложизненные ориентации» (СЖО) (Д. А. Леонтьев) и «Методика исследования самоотношения» (МИС) (С. Р. Пантилеев). Выявлено, что адекватное, сбалансированное самоотношение в сочетании с высоким уровнем сформированности смысложизненных ориентаций (стремление к реализации жизненных иелей, результативность, ответственность за свою жизнь) обеспечивает профессиональную активность студентовпсихологов, их оптимизм и веру в свои возможности.

Ключевые слова: смысложизненные ориентации, самоотношение, студенты-психологи, самоуверенность, самоценность.

Постановка проблемы. Отношение к себе как смысловое образование имеет для субъекта непреложную значимость, любое проявление человека как социального субъекта сопровождается включением в данный процесс самоотношения. В этой связи изучение данного феномена, раскрытие его места в про- цессе становления личности является насущной проблематикой современной психологии личности. Сбалансированное, позитивное самоотношение психолога является важнейшим психологическим условием его эффективного взаимодействия с клиентами. Специфика профессии психолога, ее направленность на 
оказание психологической помощи другим людям подразумевает то, что основным инструментом его работы является сама личность, помимо теоретических знаний и специальных психологических методик, эта профессия требует высокого уровня развития субъективных качеств: ценностных и смысложизненных ориентаций, мотивов, самооценки, самоотношения и др. [2, с. 281].

Анализ последних исследований. Проблема самоотношения в психологии рассматривалась многими авторами. Под самоотношением понимают самооценку (Е. Т. Соколова, А. Г. Спиркин), самоуважение (И. С. Кон, Х. Маркус); самопринятие (Д. Марвел, К. Роджерс); эмоционально-ценностное отношение (С. Р. Пантилеев, И. И. Чеснокова); систему установок, направленных на себя (Н. И. Сарджвеладзе, В. В. Столин).

Самоотношение личности понимается как сложное когнитивно-аффективное образование, зрелость которого определяется качеством взаимосвязи и степенью согласованности его составляющих. Его структура рассматривается как состоящая из двух компонентов: рационального отношения к себе как субъекту социальной активности («образ - Я» или категориальное «Я») и эмоционально-ценностного отношения к себе - переживания и оценки собственной значимости как субъекта социальной активности, образующих рефлексивное «Я». В результате взаимодействия указанных компонентов с потребностно-мотивационной сферой личности отношение к себе включается в процесс деятельностной и личностной саморегуляции, стимулирует развитие познавательной и личностной субъектности человека [4].

Отношение к себе рассматривается нами как представление личности о смысле собственного «Я», в нем раскрывается сущность человека, смысл его существования. Смысл жизни как процесс духовного и предметного освоения человеком мира и самого себя может раскрываться только через осмысление своего места в мире, то есть через смысложизненное ориентирование. Именно такие представления о самоотношении дают нам основание распространить их на характеристики личности будущего психолога и исследовать его взаимосвязь с особенностями проявлений смысложизненных ориентаций.

Целью данной статьи является изложение теоретико-эмпирических результатов исследования самоотношения будущих психологов с разным уровнем сформированности смыложизненных ориентаций.

Согласно указанной цели были поставлены следующие задачи: 1) выявить корреляционные взаимосвязи между обозначенными переменными; 3) построить и сравнить профили самоотношения, различающиеся значением общего показателя смысложизненных ориентаций; 4) определить психологические особенности испытуемых.

Методы исследования. С целью изучения специфики взаимосвязи между обозначенными переменными мы использовали методики «Смысложизненные ориентации» (СЖО) (Д. А. Леонтьев) и «Методика исследования самоотношения» (МИС) (С. Р. Пантилеев) $[1$, с. 141$]$

В исследовании принимали участие студентыпсихологи Южноукраинского национального педагогического университета имени К. Д. Ушинского (г. Одесса), Одесского национального университета имени И. И. Мечникова и Измаильского государственного гуманитарного университета. Всего в исследовании принимали участие 328 человек в возрасте от 17 до 30 лет. Математически-статистическая обработка данных осуществлялась путем расчета ранговой корреляции по Спирмену (программа SPSS, версия 17.00.). Качественный анализ проводился с помощью метода асов и профилей.

Изложение основного материала исследования. Коэффициенты корреляции между показателями смысложизненных ориентаций (СЖО) и самоотношения (МИС) представлены в таблице 1.

Таблица 1.

Значимые коэффициенты корреляций между показателями смысложизненных ориентаций и самоотночения.

\begin{tabular}{|c|c|c|c|c|c|c|c|c|c|}
\hline \multicolumn{10}{|c|}{ МИС } \\
\hline & I & II & III & IV & $\mathrm{V}$ & VI & VII & VIII & IX \\
\hline Ц & & $218 * *$ & $162 * *$ & $170 * *$ & $123 *$ & & & $-200 * *$ & $-153 * *$ \\
\hline$\Pi$ & & $254 * *$ & $208 * *$ & $279 * *$ & $188 * *$ & $174 * *$ & & $-225 * *$ & $-220 * *$ \\
\hline $\mathrm{P}$ & & $192 * *$ & $189 * *$ & $210 * *$ & $189 * *$ & $156 * *$ & $117 *$ & $-210 * *$ & $-218 * *$ \\
\hline Л-Я & & $242 * *$ & $182 * *$ & $218^{* *}$ & $154 * *$ & & $128 *$ & $-197 * *$ & $-170 * *$ \\
\hline Л-Ж & $123^{*}$ & $238 * *$ & $240 * *$ & $213 * *$ & $195 * *$ & $168 * *$ & $115^{*}$ & $-185^{* *}$ & $-189 * *$ \\
\hline
\end{tabular}

Примечание: n-328; нули и запятые опущены; ** - $\rho \leq 0,01, *$ - $\rho \leq 0,05$. Условные сокращения шкал методики СЖО: 1) Ц - цели; 2) П - процесс; 3) Р - результат; 4) Л-Я - локус контроля «Я»; 5) Л-Ж - локус контроля «Жизнь». Условные сокращения шкал МИС: I - закрытость; II -самоуверенность; III - саморуководство; IV - отраженное самоотношение; V - самоценность; VI - самопринятие; VII - самопривязанность; VIII - внутренняя конфликтность; IX - самообвинение.

Из таблицы видно, что между показателями методики МИС и СЖО существуют значимые, допол- нительные, положительные и отрицательные взаимосвязи. Положительные корреляции: 
1) на $1 \%$ уровне «самоуверенность», «саморуководство», «отраженное самоотношение», «самоценность» взаимосвязаны со всеми шкалами методики СЖО. Они указывают на то, что реализация жизненных целей студентов-психологов, результативность, процесс, регуляция жизни зависят от выраженности таких качеств, как самоуверенность, самоценность, саморуководство, самоотношение;

2) «самопринятие» значимо коррелирует со шкалами: «процесс», «результат», «локус контроля «Жизнь». Это значит, что степень принятия человеком самого себя, удовлетворенность нынешним уровнем индивидуального развития, личностных особенностей влияет на способность формировать образ желаемого будущего, брать ответственность и получать удовольствие от жизни;

$3)$ «самопривязанность» $(\rho \leq 0,05)$ коррелирует со шкалами «результат», «локус контроля «Я», «локус контроля «Жизнь». Можно утверджать, что возможность принимать решения и воплощать их в жизнь в соответствии со своими целями и задачами и представлениями о ее смысле напрямую связано с желанием изменяться по отношению к текущему состоянию.

Отрицательные значимые коррреляции:
1) «внутренняя конфликтность» и «самообвинение» на $1 \%$ уровне связаны со всеми показателями СЖО, что свидетельствует о негативном влиянии внутренней напряженности и отрицательных эмоций в адрес своего «Я» на реализацию жизненных целей, на процесс и результат жизнедеятельности, на способность контролировать свою жизнь.

Применение качественного анализа и метода «ассов» позволяет сгруппировать исследуемых по определенным признакам (в данном случае, по степени сформированности смысложизненных ориентаций). Первую группу (CЖО+) составили испытуемые с высоким уровнем общего показателя смысложизненных ориентаций (4-й квартиль распределения от 75 до 100 процентиля), вторую группу (СЖО-) - с низким уровнем (1-й квартиль распределения от 0 до 25 процентиля). Это позволило в нашей выборке выявить самых ярких представителей, которые отличаются между собой степенью сформированности СЖО и изучить особенности их самоотношения.

На рис. 1, 2, 3, 4 отображены профили самоотношения студентов-психологов разных курсов с высокой и низкой степенью сформированности СЖО.

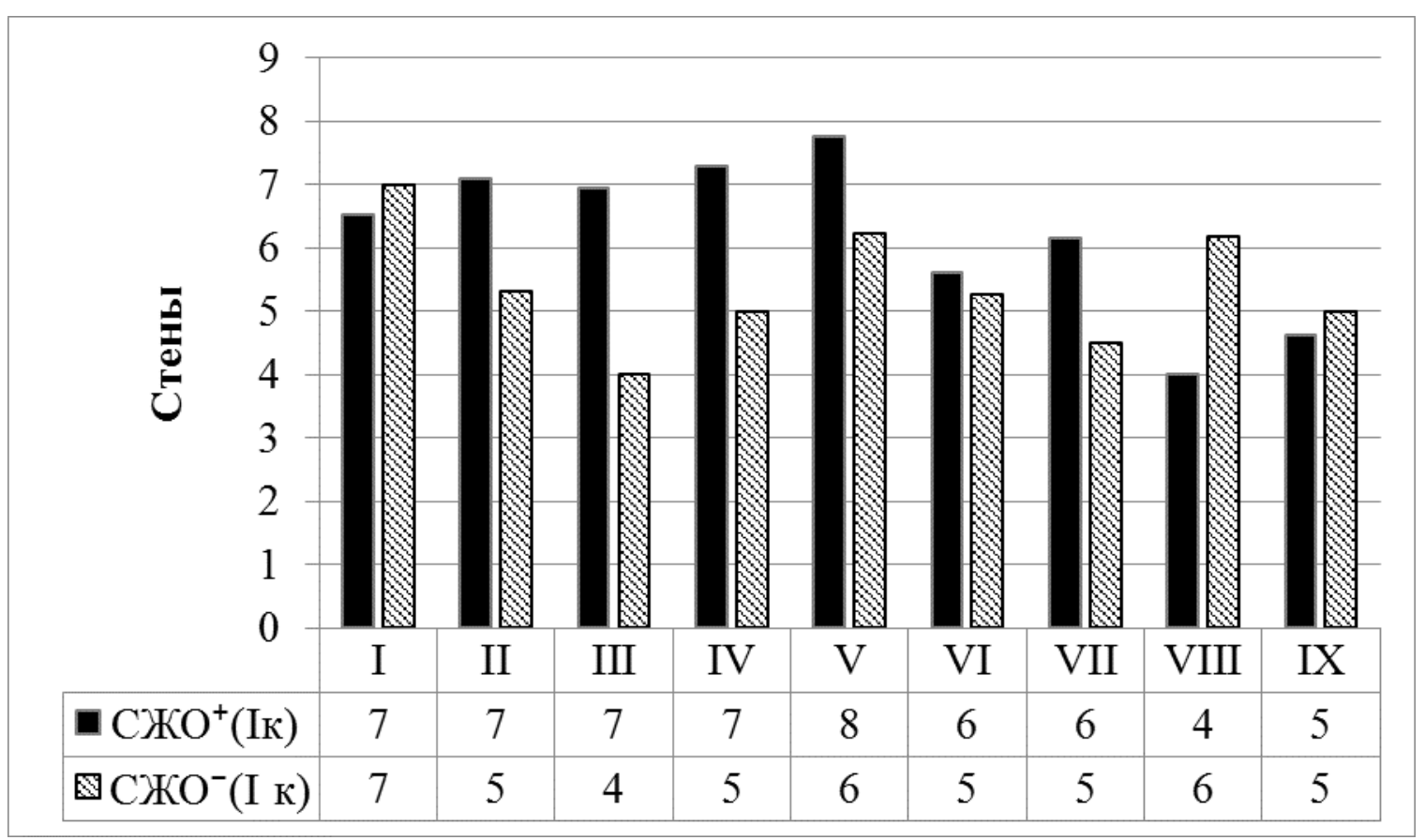

Рис. 1. Профили самоотношения групп студентов-психологов с разным уровнем СЖО (1 курсы).

Примечание: условные сокращения методики СЖО и МИС см. таб. 1.

Для того, чтобы выявить доминирующие тенденции данных показателей и описать специфику самоотношения представителей данных групп, необходи- мо проранжировать значения этих показателей в каждом профиле относительно их отклонений от средней линии ряда (в порядке уменьшения) (см. таблицу 2). 


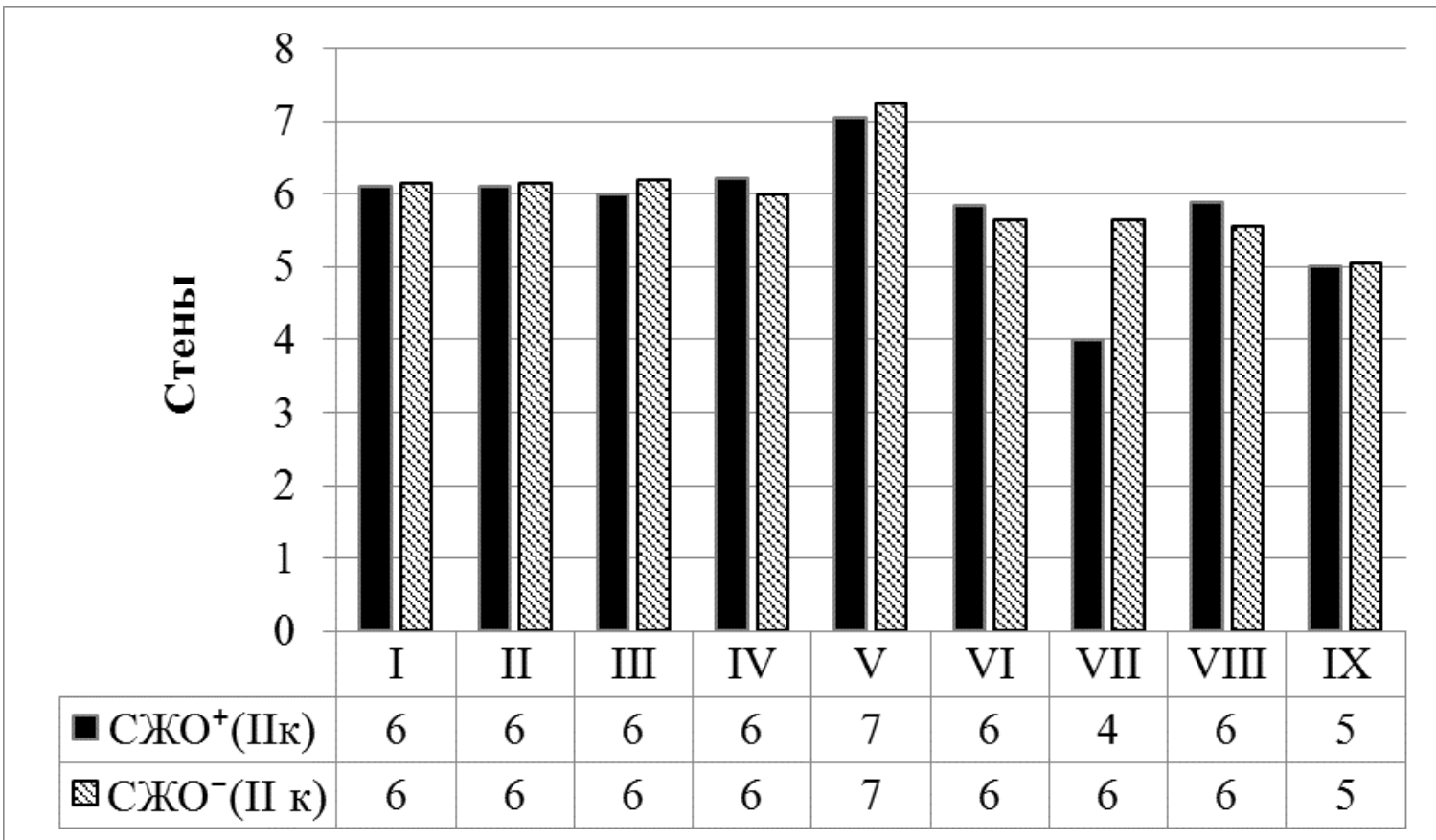

Рис. 2. Профили самоотношения групп студентов-психологов с разным уровнем СЖО (2 курсы).

Примечание: условные сокращения методики СЖО и МИС см. таб. 1.

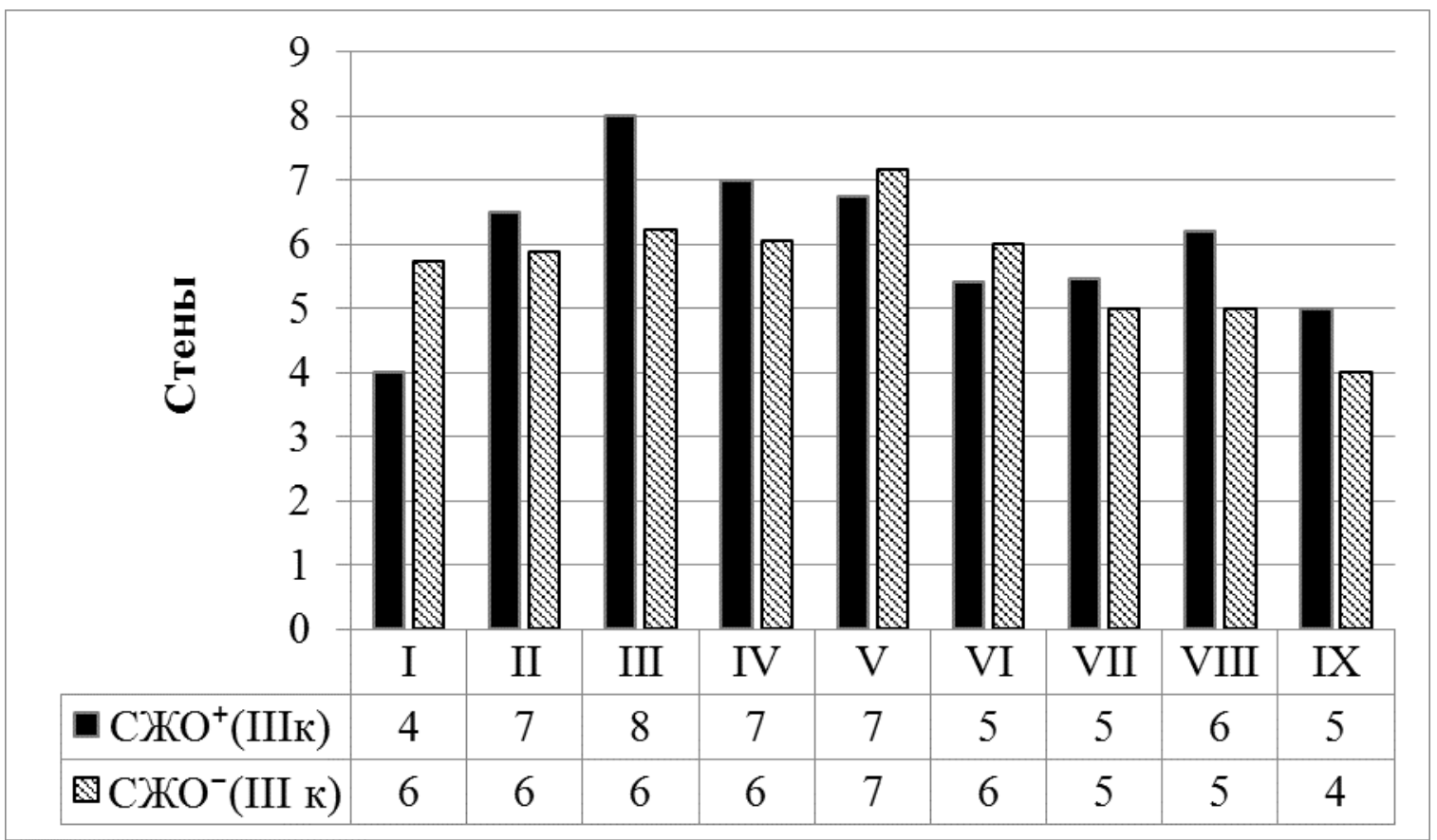

Рис. 3. Профили самоотношения групп студентов-психологов с разным уровнем СЖО (3 курсы).

Примечание: условные сокращения методики СЖО и МИС см. таб. 1. 


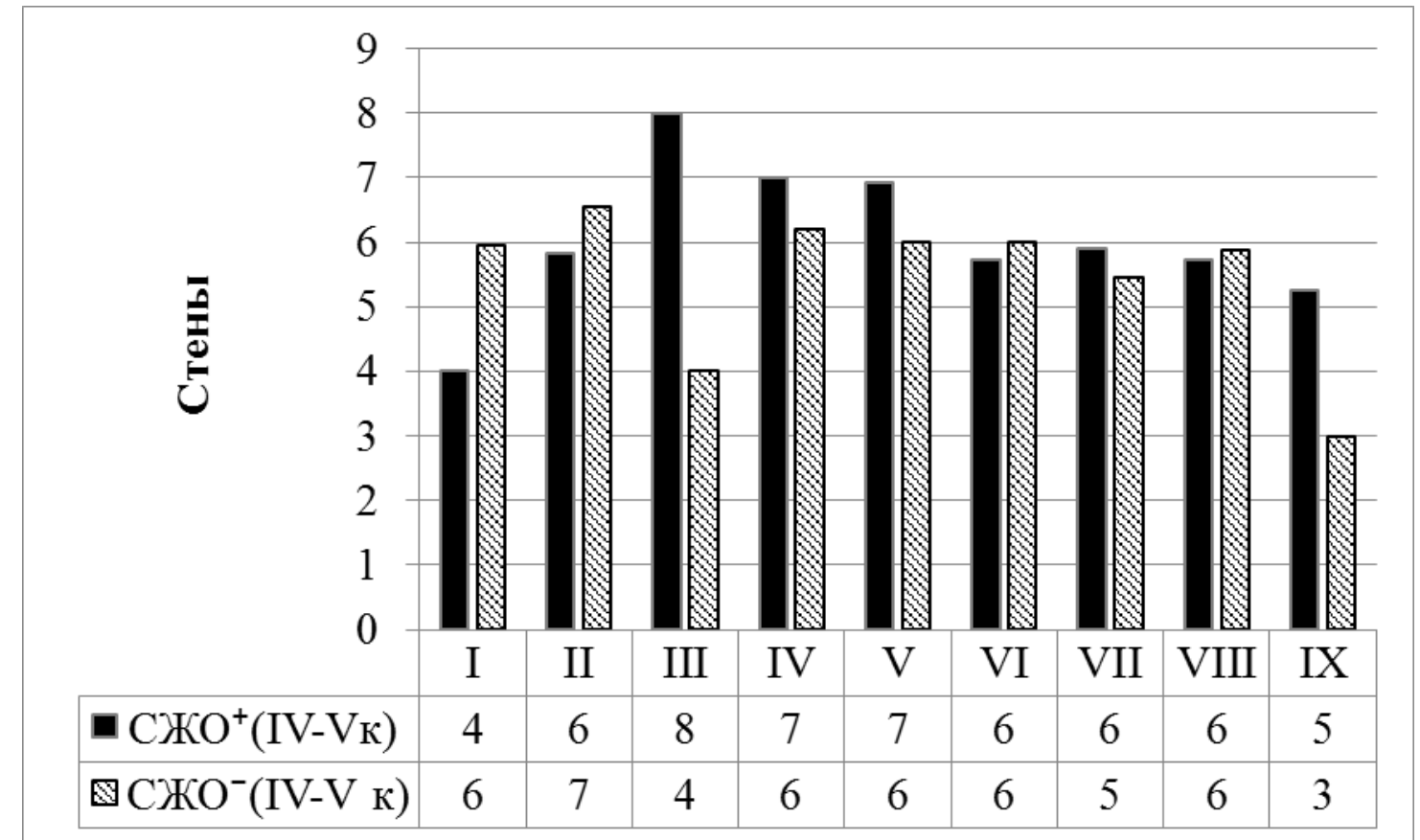

Рис. 4. Профили самоотночения групп студентов-психологов с разным уровнем СЖО (IV-V курсы).

Примечание: условные сокращения методики СЖО и МИС см. таб. 1.

Таблица 2.

Ранжирование показателей самоотночения студентов 1-5 курсов психологических факультетов с разным уровнем СЖО

\begin{tabular}{|c|c|c|c|c|}
\hline \multicolumn{5}{|c|}{ СЖО+ } \\
\hline \multirow[b]{2}{*}{ Ранг } & \multicolumn{4}{|c|}{ Курсы } \\
\hline & 1курс & 2курс & 3 курс & 4-5 курсы \\
\hline 1 & V & $\mathrm{V}$ & III & III \\
\hline 2 & I, II, III & I, II, III, IV & II, IV, V & $\mathrm{IV}, \mathrm{V}$ \\
\hline 3 & VIII & VII & I & I \\
\hline \multicolumn{5}{|c|}{ СЖО- } \\
\hline \multirow[b]{2}{*}{ Ранг } & \multicolumn{4}{|c|}{ Курсы } \\
\hline & 1 курс & 2 курс & 3 курс & 4-5 курсы \\
\hline 1 & I & $\mathrm{V}$ & $\mathrm{V}$ & II \\
\hline 2 & V, VIII & I, II, III,IV, V & I, II, III, IV,VII & $\mathrm{I}, \mathrm{IV}, \mathrm{V}, \mathrm{VI}$ \\
\hline 3 & III & IX & IX & IX \\
\hline
\end{tabular}

Примечание: условные сокращения методики УСК см. рис. 1.

Итак, рассмотрим специфику самоотношения в каждой из исследуемых групп. Сначала охарактеризуем самоотношение в группах студентов с высокой степенью сформированности смысложизненных ориентаций (см. рис. 1, 2, 3, 4).

У студентов-психологов 1 курсов группы СЖО+ доминирует показатель «самоценность», что означает, что эти студенты высоко оценивают себя, свою индивидуальность, рационально воспринимают критику. Низкие значения профиля «внутренняя конфликтность» свидетельствуют о положительном отношении к себе в целом, но в критических ситуациях такие люди склонны к обесцениванию своих достижений.
Согласно данным, представленным на рис. 2, будущие студенты 2 курсов группы СЖО+ характеризуются высокими показателями по шкале «самоценность» и низкими - по шкале «самопривязанность». Это указывает на избирательность отношения к своим личностным свойствам, на стремление к изменению лишь некоторых своих качеств при сохранении прочих других. Уверенность в себе и в своих силах помогает этим лицам противостоять средовым воздействиям.

В группе исследуемых СЖО+ 3 и 4-5 курсов доминирует показатель «саморуководство», наименее выражено значение показателя «закрытость». Таким студентам свойственно воспринимать себя координаторами своего развития, они откровенны, ответствен- 
ны, умеют контролировать эмоциональные реакции и переживания по поводу себя, действуя на основе собственных убеждений и ценностей.

Теперь охарактеризуем респондентов групп с низким уровнем сформированности смысложизненных ориентаций. У первокурсников группы СЖО- наиболее выражен конпонент «закрытость», наименне - «саморуководство». Такие студенты раскрывают особенности отношения к своему «Я» в зависимости от степени адаптированности к ситуации, у них выражено защитное поведение личности, основным источником происходящего с человеком признаются внешние обстоятельства. У студентов 2 и 3 курсов с низкой степенью сформированности СЖО выявлены высокие значения показателя «самоценность» и низкие значения - «самообвинение». Таким личностям свойственна декларация уверенности в себе в сочетании с порицанием других, поисками в них источников всех неприятностей и бед. Что касается студентов 4-5 курсов (СЖО-), то у них наибольшие значения по показателю «самоуверенность», а наименьшие - «самообвинение». Это характеризует таких молодых людей как высоко оценивающих свой потенциал, богатство своего внутреннего мира, но в то же время, в их поведении обнаруживается тенденция к отрицанию собственной вины в конфликтных ситуациях, перенесение ответственности на окружающих за устранение барьеров на пути к достижению цели, отрицание собственных проблем. Из этого следует, что завышенная самооценка снижает критичность по отношению к себе, а такие характеристики не соответствуют профессионально важным качествам профессии психолога. Самовлюбленность, непроработанные внутренние конфликты и неспособность управлять своими эмоциональными состояниями могут стать серьезным препятствием на пути разрешения жизненных сложностей клиента. Тем самым нарушается баланс между процессом и результатом психологической помощи, соблюдение которого является одним из важнейших факторов ее эффективности.

В заключение отметим, что работа психолога относится к таким видам деятельности, в которых профессиональные и личностные проявления («Я» функциональное и «Я» - экзистенциональное) пересекаются особенно тесно, а профессиональный рост невозможен без личностного. Противоречия между личностным и профессиональным самосознанием приводят к нарушениям в профессиональной идентичности психолога [3, с. 268].

Самоотношение является важным фактором в познании человеком не только себя, но и своих отно-

\section{ЛИТЕРАТУРА}

1. Настольная книга практического психолога / Сост. С. Т. Посохова, С. Л. Соловьева. - М. : АСТ: Хранитель; СПб.: Сова, 2008. - 671 с.

2. Панок В. Г. Психологічна служба: Навчальнометодичний посібник для студентів і викладачів / В. Г. Панок. - Кам'янець-Подольський : ТОВ Друкарня Рута, 2012. -488 c. шений с другими людьми и с окружающей действительностью. Такая сложная рефлексивная деятельность, то есть постоянное переживание и познание себя способствует развитию самокритичности и пластичности личности будущего психолога и обеспечивает возможность заниматься в первую очередь запросами клиента, а не самоутверждаться за счет него, не отвлекаться во время работы на свои психические состояния и переживания.

Выводы. Особенности самоотношения в группах студентов 1-5 курсов с высокой степенью сформированности смысложизненных ориентаций состоят в следующем: а) 1 курсы: студенты высоко оценивают себя, свою индивидуальность, рационально воспринимают критику, положительно относятся к себе в целом, но в критических ситуациях такие люди склонны к обесцениванию своих достижений; б) 2 курсы: таким людям характерно избирательное отношение к своим личностным свойствам, уверенность в себе и в своих силах помогает им противостоять трудностям; в) 3, 4, 5 курсы: этим студентам свойственно воспринимать себя координаторами своего развития, они открыты, откровенны, умеют контролировать эмоциональные реакции и переживания по поводу себя. Будущие психологи с низким уровнем сформированности смысложизненных ориентаций: а) студенты 1 курса раскрывают особенности отношения к своему «Я» в зависимости от степени адаптированности к ситуации, у них выражено защитное поведение личности, основным источником того, что происходит с человеком, признаются внешние обстоятельства; б) 2, 3 курсы: таким личностям свойственна декларация уверенности в себе в сочетании с осуждением других, поисками в них источников всех неприятностей и бед; в) студенты 4-5 курсов высоко оценивают себя, но в их поведении проявляется тенденция к отрицанию собственной вины в конфликтных ситуациях и собственных проблем. Вывод: адекватное, сбалансированное самоотношение в сочетании с высоким уровнем сформированности смысложизненных ориентаций (стремление к реализации жизненных целей, удовлетворенность процессом жизнедеятельности, результативность, ответственность за свою жизнь) обеспечивает профессиональную активность студентов-психологов, их оптимизм и веру в свои возможности.

Перспективы дальнейших исследований заключаются в уточнении причинно-следственных связей между смысложизненными ориентациями и другими факторами профессионального становления будущих психологов.

3. Пантилеев С. Р. Самоотношение как эмоционально-оценочная система. / С. Р. Пантилеев. - М. : МГУ, 1991. - 108 с.

4. Психология самоотношения: Учеб. пособие / А. М. Колышко. - Гродно: ГрГУ, 2004. - 102 с. 


\section{REFERENCES}

1. Posokhova, S. T. Solovieva, S. L. (2008). Nastolnaya kniga prakticheskogo psikhologa [Handbook of a practical psychologist]. Saint Petersburg: Sova [in Russian].

2. Panok, V. G. (2012). Psykholohichna sluzhba: Navchalno-metodychnyi posibnyk dlia studentiv $i$ vykladachiv [Psychological aid: textbook for students and lecturers]. Kamianets-Podolskyi: TOV Drukarnya Ruta [in Ukrainian].
3. Pantileev, S. R. (1991). Samootnoshenie kak emotsionalno-otsenochnaya sistema. [Self-attitude as an emotionally-assessment system.]. Moscow: MGU [in Russian].

4. Kolyshko, A. M. (2004). Psikhologiya samootnosheniya: Uchebnoe posobie. [Psychology of the selfattitude: textbook]. Grodno: GrGU [in Russian].

\title{
Ірина Сергї̈вна Варе, аспірант кафедри теорії та методики практичної психології, Південноукраӥнський начіональний педагогічний університет імені К. Д. Уиинського, вул. Старопортофранківська, 26, м. Одеса, Украӥна
}

\section{САМОСТАВЛЕННЯ СТУДЕНТІВ-ПСИХОЛОГІВ З РІЗНИМ СТУПЕНЕМ СФОРМОВАНОСТІ СМИСЛОЖИТТЕВИХ ОРІЄНТАЦЙ}

Збалансоване, позитивне самоставлення психолога є важливою психологічною умовою його ефективної взаємодії з клієнтами. Вивчення цього феномена, розкриття його місця в процесі становлення особистості $\epsilon$ нагальною проблематикою сучасної психології особистості. Метою статті $є$ виклад теоретико-емпіричних результатів дослідження самоставлення майбутніх психологів із різним рівнем сформованості смиложиттєвих орієнтацій. За допомогою кореляційного аналізу виявлено, що між показниками методики МДС і СЖО існують значущі, додаткові, додатні та від'ємні і негативні взаємозв'язки. Особливості самоставлення в групах студентів 1-5 курсів з високим ступенем сформованості смисложиттєвих орієнтацій полягають в наступному: а) студенти 1 курсів високо оцінюють себе, свою індивідуальність, раціонально сприймають критику, позитивно ставляться до себе в цілому, але в критичних ситуаціях такі люди схильні до знецінення своїх досягнень; б) студентам 2 курсів характерно вибіркове ставлення до своїх особистісних властивостей, впевненість в собі та в своїх силах допомагає їм протистояти труднощам; в) 3, 4, 5 курси: цим студентам властиво сприймати себе координаторами свого розвитку, вони відкриті, відверті, вміють контролювати емоційні реакції і переживання 3 приводу себе. Майбутні психологи з низьким рівнем сформованості смисложиттєвих орієнтацій: а) 1 курс: ці студенти розкривають особливості ставлення до свого «Я» в залежності від ступеня адаптованості до ситуації, у них вираженою є захисна поведінка особистості, основним джерелом того, що відбувається з людиною, визнаються зовнішні обставини; б) 2, 3 курси: цим особистостям властива декларація впевненості в собі в поєднанні 3 осудженням інших, пошуками в них джерел всіх неприємностей і бід; в) студенти 4-5 курсів високо оцінюють себе, але в їхній поведінці виявляється тенденція до заперечення власної провини в конфліктних ситуаціях $\mathrm{i}$ власних проблем. Отже, ступінь сформованості смисложиттєвих орієнтацій та особливості самоставлення $\epsilon$ факторами професійного становлення особистості психолога, від яких залежить активність особистості в досягненні успіхів у професійній діяльності.

Ключові слова: смисложиттєві орієнтації, самоставлення, студенти-психологи, самовпевненість, самоцінність.

\author{
Iryna Vare, \\ post-graduate student, \\ Department of Theory and Methods of Practical Psychology, \\ South Ukrainian National Pedagogical University named after K. D. Ushynsky, \\ 26, Staroportofrankovska Str., Odesa, Ukraine
}

\section{SELF-ATTITUDE OF STUDENTS-PSYCHOLOGISTS WITH DIFFERENT LEVELS OF VALUE ORIENTATIONS MATURITY}

Balanced positive self-attitude of a psychologist is an important psychological condition for his/her efficient interaction with counselees. The study of this phenomenon, the revealing of its place in the process of personal development is an urgent problem of modern personality psychology. The article is aimed at presenting theoretical and empirical results of researching self-attitude of future psychologists with different levels of value orientations maturity. With the help of the correlation analysis it has been found that the peculiarities of self-attitude of $1-5^{\text {th }}$ year students with the high level of value orientations maturity lie in the following: a) 1st year students are characterized by high self-esteem, they are able to accept criticism, have positive self-attitude, but in critical situations are prone to underestimate their own achievements; b) $2^{\text {nd }}$ year students demonstrate self-belief which helps them to overcome difficulties; c) 3-4th year students consider themselves to be the coordinators of their development, they are fair and are able to control different 
emotional reactions and criticism. Future psychologists with the low level of value orientations maturity are described as follows: a) $1^{\text {st }}$ year students reveal the peculiarities of self-attitude depending on the level of the adjustment to a situation, they are also characterized by the defensiveness; b) $2^{\text {nd }}$ and $3^{\text {rd }}$ year students always show their self-confidence and judge other people, trying to blame them in every difficult situation; c) $4-5^{\text {th }}$ year students have very high selfesteem, but they tend to deny their own guilt in conflict situations and problems. Thus, the level of value orientations maturity and the peculiarities of self-attitude are the factors of the professional development of a psychologist that determine the success of his/her career.

Keywords: value orientations, self-attitude, students-psychologists, self-confidence, self-worth.

Рецензент: д. психол. н., проф. Л. К. Велитченко

Подано до редакизї 05.07.2016 